\title{
Study on Tomato Wine Production and Optimization
}

\author{
Josephine Nirmala Many, B. Radhika and T.Ganesan \\ Department of Home Science, Avvaiyar Govt. College, Karaikal. \\ Department of Home Science, Bharathidasan Govt. College for Women, Pududcherry. \\ Department of Botany, Tagore Arts college, Puducherry.
}

\begin{abstract}
Wine is a typical alcoholic beverage produced by natural alcoholic ferementation of fruit juice of sound quality. Wine consists of (10-12\%) of ethanol. The suitability of tomato fruit was investigated for the production of tomato wine. Fermentation of tomato juice was carried out by a potent yeast strain Saccharomyces cerevisiae (MTCC 180). The production of tomato wine was standardized with reference to different variables such as, size of inoculums, $p H$ of tomato juice, time of fermentation (1-10 days), adjustment of brix, Incubation temperature, effect of alcohol adapted \& non-adapted cultures and age of culture. The tomato wine was analysed for $\mathrm{pH}$, total soluble solids (TSS), titratable acidity (TA) and ethanol concentration.

The maximum production of ethanol was achieved on $4^{\text {th }}$ day of fermentation with $24^{\circ}$ Brix at $5 \%$ inoculums level. The production of wine using alcohol adapted culture and non-adapted cultures showed no significant change in ethanol content. Hence, better quality wine can be prepared using non-adapted culture on $4^{\text {th }}$ day of fermentation is considered optimum.
\end{abstract}

Keywords: Saccharomyces cerevisiae, Potassium meta bisulphate, total soluble solid, fermentation and titratable acidity.

\section{Introduction:}

Tomato is the world's largest vegetable crop, because of its wide spread production and special nutritive value. It is a rich source of vitamin A and C, it also contains minerals like iron, phosphorus and pigments such as Lycopene and Beta-carotene.Tomato is commonly used in preserved products like ketch-up, sauce, chutney, soup, paste, puree etc. Apart from these food products, tomato is also used to prepare wine due to its easy availabitlity and its nutritional property. Wine is an alcoholic beverage made from fermented fruit juice usually that of grapes. The consumption of wine has several health benefits like lowering the mortality from cardiovascular disease and cancer, delaying dermentia and preventing arthritis (Robinson, 2006). The studies related to tomato wine was very few so, the suitability of tomato juice for wine making was tested.

\section{OBJECTIVES}

$>$ To prepare tomato wine.

$>$ To optimize tomato wine with different variables.

\section{Methodology:}

Ripe tomato fruits $(1 \mathrm{~kg})$ was purchased from local market and washed in tap water. The tomato were cut into pieces and made into pulp by grinding $(5 \mathrm{~min})$ in a mixi. The pulp was strained through a tea strainer to collect the juice $(500 \mathrm{ml})$ and the $\mathrm{pH}$ was 4.6 . The juice was adjusted to $22^{\circ}$ Brix by adding sugar $(275 \mathrm{~g} / \mathrm{lit})$. Then required volume of juice was dispensed into boiling tubes and pasteurised at $80^{\circ} \mathrm{C}$ for $4-5$ minutes. The tubes were inoculated with 24hour old Saccharomyces cerevisiae (MTCC 180) to get a final concentration of $7 \%$ and incubated at $28 \pm 2^{\circ} \mathrm{C}$ for definite period. It was analysed further for its $\mathrm{pH}$, titratable acidity (TA), total soluble solids (TSS) and ethanol content. The following schematic diagram enumerate the tomato wine making process in the fig 1.

Optimization of fermentation process: Tomato wine fermentation was tested considering the following parameters.

The following variables were optimized to prepare good quality wine. They are as follows:

- Incubation period (1 to 8 days)

- Size of inoculums $(5,7,10,12$ and $15 \%)$

- $\mathrm{pH}$ of the juice $(3.5,4.5,5.5$ and 6.5$)$

- Adjustment of brix $\left(20,22,24\right.$ and $\left.26^{\circ} \mathrm{B}\right)$

- Incubation temperature $\left(20,25\right.$ and $\left.30^{\circ} \mathrm{C}\right)$

- Alcohol adapted and Non-adapted culture

- Age of culture (24 hour and 48 hour culture) 


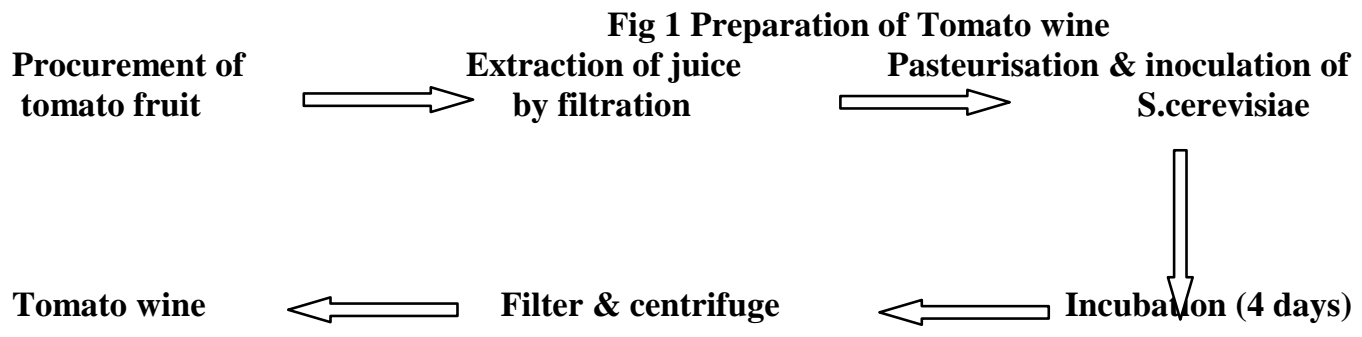

\section{RESULTS:}

Physicochemical characteristics of wine after completion of fermentation under optimized environmental condition were studied. $\mathrm{pH}$, titratable acidity, total soluble solids and ethanol content were recorded for all the variables. The quality of wine can be characterised by its ethanol content which is the chief component found in all types of wine (Joshi, 1998).

\section{Results And Discussion}

Optimization of incubation period for tomato wine preparation:

The incubation time for tomato wine was standardised by analysing for a period of $1-8$ days which is given in the table 1.

Table 1 - Optimization of incubation period for tomato wine preparation

\begin{tabular}{|c|c|c|c|c|}
\hline & $\mathbf{p H}$ & TSS & TA & Ethanol \\
\hline 1 & 4.13 & 12.6 & 0.32 & 10.90 \\
\hline 2 & 4.15 & 5.4 & 0.48 & 14.79 \\
\hline 3 & 4.15 & 5.1 & 0.61 & 17.03 \\
\hline 4 & 4.33 & 5.0 & 0.38 & 18.71 \\
\hline 5 & 4.36 & 4.8 & 0.38 & 15.61 \\
\hline 6 & 4.28 & 4.8 & 0.48 & 14.18 \\
\hline 7 & 4.28 & 4.7 & 0.45 & 13.52 \\
\hline 8 & 4.39 & 4.7 & 0.48 & 9.13 \\
\hline
\end{tabular}

The longer the incubation time, the resulting ethanol content increased. The highest level of ethanol was produced on $4^{\text {th }}$ day with ethanol content of $18.71 \%$. Results of research from Putri and Sukandar showed that ethanol production from canna starch using S.cerevisiae, the maximum ethanol concentration achieved during fermentation at the $24^{\text {th, }}$ and began to decline at the $36^{\text {th }}$ hour. This is because on the $24^{\text {th }}$ hour yeast entered the phase exponentially, while at the $36^{\text {th }}$ hour yeast cell begin to enter stationary phase. And also the ethanol content in wine is influenced by method of wine preparation, type of yeast used and initial TSS in juice.

\section{Size of inoculum on tomato wine production}

The size of inoculum on wine fermentation is of great importance in completing the fermentation process. Different levels of inoculum $(5,7,10,12 \& 15 \%)$ were used to inoculate the fermentation mixture.

Table 2 - Effect of inoculums size on tomato wine production

\begin{tabular}{|l|l|l|l|l|}
\hline Inoculum size (\%) & $\mathbf{p H}$ & TSS (\%) & TA & Ethanol (\%) \\
\hline 5 & 3.90 & 5.4 & 0.32 & 15.50 \\
\hline 7 & 3.93 & 5.2 & 0.35 & 9.18 \\
\hline 10 & 3.99 & 5.2 & 0.32 & 11.02 \\
\hline 12 & 3.98 & 5 & 0.32 & 13.90 \\
\hline 15 & 3.98 & 5 & 0.35 & 15.50 \\
\hline
\end{tabular}

It was observed from the table 5 that maximum ethanol production was observed at $5 \%$ inoculum size. Further increase in inoculum size did not favour ethanol production. It was, therefore, concluded that $5 \%$ inoculums is the optimum and selected for further studies.

\section{Effect of pH of tomato juice}

The $\mathrm{pH}$ of juice is important parameter for the successful progress of fermentation. Control of $\mathrm{pH}$ during wine fermentation is important for two reasons (a) the growth of harmful bacteria is retarded by acidic 
solution (b) yeast grows well in acidic conditions (Mathewson, 1980). So, different $\mathrm{pH}$ ranges from 3.5 to 6.5 was tested for tomato juice concentrate.

Table 3 - Optimization of $p H$ of tomato juice for wine making

\begin{tabular}{|l|l|l|l|l|}
\hline pH of the juice & pH & TSS & TA & Ethanol \\
\hline 3.5 & 3.44 & 5 & 0.55 & 19.69 \\
\hline 4.5 & 3.91 & 5 & 0.45 & 18.46 \\
\hline 5.5 & 4.10 & 5 & 0.51 & 17.09 \\
\hline 6.5 & 4.30 & 4.6 & 0.45 & 14.38 \\
\hline Control $\quad(\mathrm{pH}=3.82)$ & 3.54 & 5.1 & 0.64 & 13.97 \\
\hline
\end{tabular}

The result showed that the maximum alcohol content was achieved during the $\mathrm{pH}$ of 3.5. With increase in $\mathrm{pH}$ the ethanol content was reduced gradually, because yeast produce acid rather than alcohol with increase in $\mathrm{pH}$ (Hodge \& Hilderbrandt, 1954). So, $3.5 \mathrm{pH}$ was considered optimum for further studies.

\section{Effect of Total soluble solid concentration of tomato wine}

The effect of total soluble solid on tomato wine preparation was studied after 4 days of incubation by carrying out at various soluble solid concentration of $20^{\circ}$ Brix to $26^{\circ}$ Brix. The results were presented in the table 4.

Table 4 - Effect of Total Soluble solid (TSS) on alcohol content

\begin{tabular}{|l|c|c|c|c|}
\hline $\begin{array}{c}\text { Brix } \\
(\%)\end{array}$ & pH & $\begin{array}{c}\text { TSS } \\
(\%)\end{array}$ & TA & $\begin{array}{c}\text { Ethanol } \\
(\%)\end{array}$ \\
\hline 20 & 4.49 & 4.5 & 0.35 & 10.86 \\
\hline 22 & 4.47 & 5 & 0.32 & 11.17 \\
\hline 24 & 4.47 & 5 & 0.32 & 12.8 \\
\hline 26 & 4.44 & 5 & 0.32 & 12.14 \\
\hline Control & 4.7 & 2 & 0.32 & 1.58 \\
\hline
\end{tabular}

The result shows that increase in ethanol production was observed with increase in total soluble solid upto $24^{\circ} \mathrm{Brix}$ and then decreased. It has been observed that initial sugar level (control) greatly affects the rate of fermentation. The use of sugar substrate is one of the ways to obtain high ethanol yield during fermentation. But, higher sugar concentration is inhibitory to fermentation due to osmotic stress (Jones et al, 1981). There are reports that high sugar senstivity (osmotolerance) in S.cerevisiae is due to higher intracellular accumulation of ethanol (Strehalaiano et al, 1983).

\section{Optimization of Incubation temperature}

Different levels of temperature was studied to optimize wine preparation. They are 20,25 and $30^{\circ} \mathrm{C}$ and illustrated in the table below:

Table 5 -Optimization of incubation temperature to prepare wine

\begin{tabular}{|c|c|c|c|c|}
\hline \multirow{2}{*}{ Temperature $\left({ }^{\mathbf{}} \mathbf{C}\right)$} & \multicolumn{4}{|c|}{ Parameters } \\
\cline { 2 - 5 } & $\mathbf{p H}$ & TSS & TA & Ethanol \\
\hline 20 & 3.88 & 6.9 & 0.45 & 16.47 \\
\hline 25 & 3.80 & 5.8 & 0.51 & 20.96 \\
\hline 30 & 3.88 & 5.9 & 0.45 & 19.20 \\
\hline
\end{tabular}

The table shows the effect of changing temperature on fermentation rate and reduction in TSS content. As the temperature increases initial fermentation rate are increased due to the enzyme activity of the metabolic pathway. And also higher temperature had negative effect on stability of enzymes or any other biomolecules and decrease the enzyme activity (Journal of Food Processing and Technology, 2011). So, at $25^{\circ} \mathrm{C}$ gives the higher alcohol yield as well as the fermentation rate is constant when compared to other temperature.

\section{Utilization of alcohol adapted and non adapted S.cerevisiae culture in wine preparation:}

The term adapted is referred as modifying the environment of microorganism (S.crervisiae), such that the S.cerevisiae develop the ability to live and thrive in different environmental conditions (Randall Padgett, 2012). S.cerevsiae was in adapted in 10 percent concentration of ethyl alcohol during culture preparation to produce alcohol more efficiently than acclimated (non adapted) culture. These alcohol adapted culture was used in wine making to analyse the difference in alcohol content of adapted and acclimated culture (table 6).

Table 6 - Analysis of tomato wine with alcohol adapted and non adapted culture

\begin{tabular}{|c|l|l|l|l|}
\hline Days & pH & TSS (brix \%) & TA & Ethanol $(\%)$ \\
\hline
\end{tabular}




\begin{tabular}{|l|l|l|l|l|l|l|l|l|}
\hline & AA & NA & AA & NA & AA & NA & AA & NA \\
\hline 0 & 4.24 & 4.23 & 22 & 22 & 0.32 & 0.32 & - & - \\
\hline 5 & 3.88 & 3.88 & 5 & 5 & 0.90 & 0.83 & 18.21 & 17.42 \\
\hline 10 & 3.86 & 3.84 & 4.7 & 4 & 0.90 & 0.90 & 14.38 & 11.17 \\
\hline 15 & 3.60 & 3.38 & 3.2 & 4 & 0.51 & 0.51 & 10.81 & 10.61 \\
\hline
\end{tabular}
*AA - Alcohol Adapted
*NA - Non Adapted

The table 6 shows that the pH, TSS, TA and alcohol content of both the AA \& NA culture. Alcohol content was slightly higher in alcohol adapted culture fermentation than the normal culture. However, the increase was not significant. The alcohol content was maximum at $5^{\text {th }}$ day of incubation and then decreased for both cultures. Therefore, NA culture was used for further study, because alcohol adapted culture has not provide rapid growth in ferementation rates as well as in alcohol production.

\section{Age of culture}

The age of culture ( 24 hour or 48 hour old culture) for tomato wine preparation was optimized by analyzing different parameters (table 5)

Table 7 - Effect of Age of culture on tomato wine preparation

\begin{tabular}{|c|c|c|c|c|}
\hline Culture age & $\mathbf{p H}$ & TSS & TA & Ethanol \\
\hline 24 hour & 4.00 & 5 & 0.38 & 14.38 \\
\hline 48 hour & 4.00 & 5.4 & 0.38 & 12.34 \\
\hline
\end{tabular}

The table shows that 24 hour old yeast culture shows maximum (14.38\%) alcohol production when compare to 48 hour old culture. This may be due to decline in the growth rate of cells after 24 hour and also the transition of population into the stationary phase. (Polish journal of food and nutrition sciences) So, for further study 24 hour old yeast culture was used.

\section{Conclusion:}

Tomato is a common and cheap vegetable available throughout the year and in huge quantities during the season. Excess production of tomato during the early summer seasons is wasted due to low market price. The present study indicates that the tomato can be converted into value added product through fruit fermentation.. From the study following conclusions were drawn. The tomato wine can be fermented at 4 days of incubation by adjusting the $\mathrm{pH}$ of the juice at 3.5 and utilizing $5 \%$ inoculum level. The optimum temperature for tomato wine fermentation was $25^{\circ} \mathrm{C}$. The 24 hour old non-adapted Saccharomyces culture was suitable for the study. So, it is possible to prepare acceptable quality of wine by optimizing the mentioned parameters.

I thank UGC for providing fund to carry out this project.

\section{Acknowledgement}

\section{Bibliography}

[1]. J. Robinson (ed) "The Oxford Companion to Wine" Third Edition pg 341-342 Oxford University Press $2006 \underline{\text { ISBN }}$ 0-19-860990-6

[2]. Joshi. V.K. Fruit wines 1998. $2^{\text {nd }}$ Ed.Directorate of extension, Dr. YS Parmer University of Horticulture \& Forestry, Nauni, Solan, India

[3]. Putri, L.S.E. and D. Sukandar (2008), Starch conversion Canna into ethanol through acid hydrolysis and fermentation, biodiversitas, 9(2), $112-116$

[4]. Mathewson, W.S. 1980, The Manual for the home and farm production of alcohol fuel. In: farm production of alcohol fuel. J.A. Diaz publication.

[5]. Hodge, M.H., Hildebrandt, M.F. 1954. Alcoholic fermentation of molasses. In: Underkofler A.L, Hickey J.R (eds) Industrial fermentation. Chemical publishing Co. Newyork.

[6]. Jones RP, Pamment N, Greenfield PF (1981). Alcohol ferementation by yeasts the effect of environmental and other variables. Proc. Biochem., 16: 42-49.

[7]. Strehalaiano P, Goma G (1983). Effect of initial substrate concentration on two wine yeasts: Relation between glucose sensitivity and ethanol inhibition. Am. J. Enol. Vitic., 34(1): 1-5.

[8]. Journal of Food Processing and Technology 2011, 2:4. Sevda SB \& Rodrigues L.

[9]. Randall Padgett, 2012, Adapted culture for cellulosic fermentation, Alternate Green Technologies, US. 